\title{
Atmospheric deposition at four forestry sites in the Alpine Region of Trentino- South Tyrol, Italy
}

\author{
Flavio MARCHETTI*, Danilo TAIT ${ }^{1)}$, Paolo AMBROSI and Stefano MINERBI ${ }^{2)}$ \\ Istituto Agrario di S. Michele all'Adige (IASMA), I-38010, S. Michele all'Adige (TN), Italy \\ ${ }^{1)}$ Laboratorio Biologico, Agenzia Provinciale per la Protezione dell'Ambiente (APPA-BZ), I-39055, Laives/Leifers (BZ), Italy \\ ${ }^{2)}$ Provincia Autonoma di Bolzano, Ripartizione Foreste, I-39100, Bolzano/Bozen, Italy \\ *e-mail corresponding author: marchetti.flavio@provincia.tn.it
}

\begin{abstract}
The Trentino-South Tyrol Region is located in the southern part of the Alpine Chain. The territory is largely mountainous with crystalline rock formations dominant in the north and limestone in the south-east. Most of the land is open to the climatic and atmospheric influence of the River Po, via the mainly $N$-S oriented valley of the River Adige. The forestry authorities of the region have since the 80s been making an annual assessment of forest decline, particularly as regards parasite attacks, defoliation and crown discoloration, and have found the situation to be better than in most other parts of Europe. The region's forest protection policy is administered by the two provinces of Bolzano/Bozen and Trento in the framework of the European convention on Long Range Transboundary Air Pollution (UN-ECE LRTAP); each province operates two forestry sampling permanent plots. The sites are all constituted according to the standard recommendations, and are located in the central part of the region along the Adige Valley, where most of population live and where most of the agriculture and industry is. Two of the areas are in coniferous stands of the typical Alpine forest, mainly composed of Norway spruce; the other two are located in deciduous stands (both high forest and coppice) and are closer to the urban centres than the first two. Concentration and deposition values for the main ionic components in bulk, wet, throughfall, stemflow and soil water are given separately for the four monitoring sites, with reference to the period $1996-$ 1999. The major acidifying component in atmospheric precipitation is still sulphate, but as other investigations confirm, the relative importance of the nitrate input is increasing all the time. The effect of these changes is probably positive for terrestrial ecosystems in the short term because of the decrease in total acidifying input and the increase in inorganic fertilisation. The absence of major "forest" damage, outlined in the annual forest damage survey reports issued by the forestry authorities (internal reports since 1983), suggests that the current atmospheric acidic load is in balance with the stational and climatic conditions.
\end{abstract}

Key words: integrated monitoring, pollutant deposition, rainfall regime, Trentino-South Tyrol

\section{INTRODUCTION}

The Trentino-South Tyrol Region is a largely mountainous area in the southern part of the Alpine Chain. Almost the whole of the region corresponds to the northern part of the watershed of the River Adige, which drains into the Adriatic Sea near Venice.

Much of the land lies above the timberline (approx. $1900 \mathrm{~m}$ a.s.l.) and is characterised by pasture, rocks and glaciers $(30 \%)$, with a smaller part comprising valleys and hilly areas $(10 \%)$, where most of the population live. The rest of the land is covered with forests, which occupy approximately $50 \%$ of the entire regional territory. This forested land, mainly comprising coniferous stands (Picea excelsa, Larix decidua, Pinus sylvestris, Abies alba, Pinus cembra, Pinus nigra in order of decreasing importance), is extremely important both economically and for its ecological and recreational value. For this reason the two autonomous provinces of Bolzano/Bozen and Trento have a major interest in research projects dealing with forest decline, and have instituted experimental areas to monitor the effect of transboundary air pollution on natural ecosystems (EMEP 1996).

\section{METHODS}

\subsection{Study areas}

The four permanent plots are located in the Adige Valley along the main lines of communication (Fig. 1). All the plots have been included since 1993 in the International Co-operative Program "ICP-IM"; the sites of Lavazè Pass and Renon/Ritten were subsequently also incorporated in the "CONECOFOR" national forestry monitoring network (Ambrosi et al. 1998). The sites of Renon/Ritten, Monticolo/Montiggl and Lavazè Pass are located about $20 \mathrm{~km}$ from each other in the central part of the region, near the town of Bolzano; the other site, Pomarolo, is situated in a different orographic context $75 \mathrm{~km}$ from the station of Renon/Ritten, and roughly 60 $\mathrm{km}$ from Monticolo/Montiggl and Lavazè Pass. The main characteristics of the sites are given in table 1 .

\subsection{Sampling and analytical methods}

Forest areas of roughly 0.25 hectares are fenced off to exclude the passage of people and large animals. These enclosed areas are equipped with 16 throughfall samplers (for rainfall), 3 stemflow samplers (for water

Paper partly prepared within the CONECOFOR programme, by the contract with the Ministry for Agriculture and Forestry Policy - National Forest Service, Italy. CONECOFOR is part of the Pan-European Level II Intensive Monitoring of Forest Ecosystem and is co-sponsored by the European Commission. 
Tab. 1. Site characteristics.

\begin{tabular}{lll}
\hline Site & Renon/Ritten & Monticolo/Montiggl \\
\hline Latitude (int. system) & $46^{\circ} 35^{\prime} 20^{\prime \prime}$ & $46^{\circ} 25^{\prime} 37^{\prime \prime}$ \\
Longitude & $11^{\circ} 26^{\prime} 04^{\prime \prime}$ & $11^{\circ} 17^{\prime} 49^{\prime \prime}$ \\
Altitude & $1750 \mathrm{~m}$ a.s.l. & $530 \mathrm{~m}$ a.s.l. \\
Avg. annual temperature & $+4.1^{\circ} \mathrm{C}$ & $+11.4^{\circ} \mathrm{C}$ \\
Avg. annual precipitation & $970 \mathrm{~mm}$ & $800 \mathrm{~mm}$ \\
Lithology & quartz porphyritic rock & quartz porphyritic \\
Vegetation zone & Picetum subalpinum & Quercetum pubescentis \\
Tree species & Norway spruce, larch, stone pine & oak, Scots pine, sweet chestnut \\
Underwood species & blueberry & - \\
Soil type & podzol & acid brown soil \\
\hline Site & Lavazé Pass & Pomarolo (Servis) \\
\hline Latitude (int. system) & $46^{\circ} 21^{\prime} 37^{\prime \prime}$ & $45^{\circ} 56^{\prime} 41^{\prime \prime}$ \\
Longitude & $11^{\circ} 29^{\prime} 42^{\prime \prime}$ & $11^{\circ} 03^{\prime} 28^{\prime \prime}$ \\
Altitude & $1780 \mathrm{~m}$ a.s.l. & $670 \mathrm{~m}$ a.s.1. \\
Avg. annual temperature & $+3.9^{\circ} \mathrm{C}$ & $+11.0^{\circ} \mathrm{C}$ \\
Avg. annual precipitation & 1100 mm & 1150 mm \\
Lithology & quartz porphyritic & Jurassic/Cretaceous limestone \\
Vegetation zone & Picetum subalpinum & Quercetum pubescentis \\
Tree species & Norway spruce, stone pine & oak, walnut, birch, ash \\
Underwood species & blueberry & - \\
Soil type & podzol & cambisol \\
\hline & &
\end{tabular}

running down the trunks) and 5 lysimeters for sampling the water in the soil. Other enclosures nearby contain meteorological instruments and open field precipitation sampling devices, for both bulk and wet deposition.

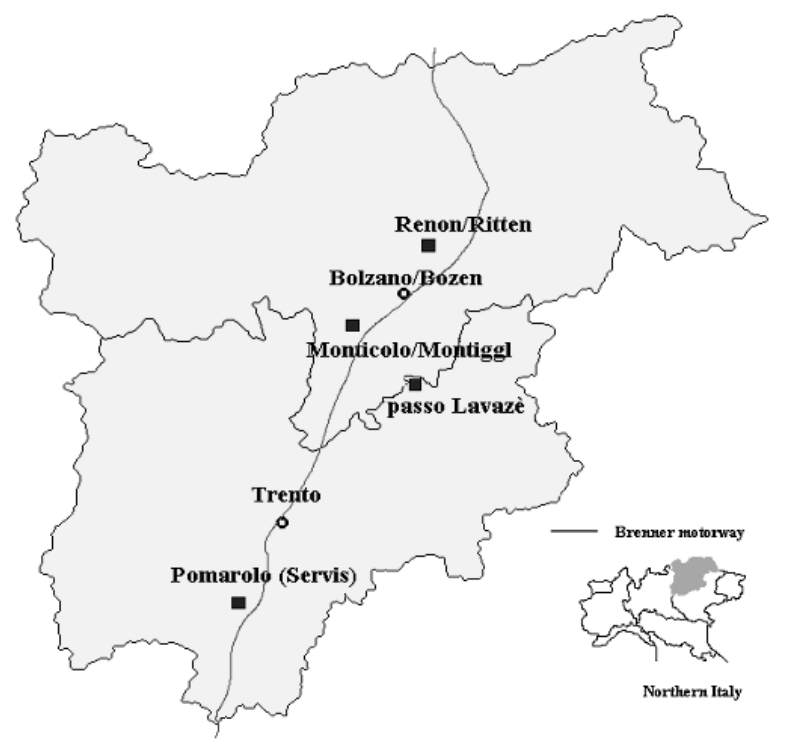

Fig. 1. Location of the sampling sites (squares) and main towns (circles) in the Region Trentino-South Tyrol.

The four areas are visited weekly by personnel responsible for collecting the samples, checking the instruments and carrying out various measurements; the precipitation volume is registered and the samples mixed to obtain the final sample for analysis (Tab. 2). Since it first began monitoring the chemistry of atmos- pheric precipitation, the "Laboratorio Biologico APPABZ (Agenzia Provinciale Protezione Ambiente)" has participated in periodic national and international exercises for the intercalibration of rain analyses (Mosello et al. 1998, 1999a). The "Laboratorio Chimico IASMA (Istituto Agrario di S. Michele all'Adige)" joined the intercomparison 1/98 for laboratories participating in the ICP Forest programme, and has performed analyses of samples from the Lavazè Pass site since 1997.

The water percolating through the soil has been analysed since 1993 at Renon/Ritten and since 1996 at the other sites. Samples are collected with 5 lysimeters (ZTL, zero tension lysimeter) at each site, placed in the soil at a depth of about $15 \mathrm{~cm}$ at Renon/Ritten and Monticolo/Montiggl, and 35-40 $\mathrm{cm}$ at Lavazè and Pomarolo. Samples are collected weekly at Renon/Ritten and Monticolo/Montiggl, and monthly at Lavazè and Pomarolo.

Precipitation volume, $\mathrm{pH}$, conductivity, alkalinity and concentrations of main ions (sulphate, nitrate, chloride, calcium, magnesium, sodium, potassium and ammonium) were determined for each sample. Net acidity and potential acidity were calculated on weekly weighted averages for open field and throughfall deposition (Mosello \& Marchetto 1996).

\section{RESULTS}

\subsection{Rainfall regime and precipitation}

The main factors affecting the distribution of rainfall over the region are firstly the distance of a common zone from the flat areas located both to the south (the plain of the Po and the Adriatic Sea) and the north (the 
Tab. 2. Analytical methods used.

\begin{tabular}{lcc}
\hline Variable & Laboratorio Chimico IASMA & Laboratorio Biologico APPA-Bz \\
\hline $\mathrm{pH}$ & Potentiometric & Potentiometric \\
Conductivity & Conductimetric & Conductimetric \\
Ammonium & Spectrophotometric (Verdow et al. 1978) & Spectrophotometric (Wagner 1969) \\
$\mathrm{Ca}, \mathrm{Mg}, \mathrm{N}, \mathrm{K}$ & Atomic absorption spectrophotometry & AAS or ion chromatography \\
Alkalinity & Potentiometric titration, detect. end point 4,5 & Gran titration (Gran 1952) \\
Sulphate & Turbidimetry (APHA 1992) & Ion chromatography \\
Nitrate & Spectrophotometry (APHA 1992) & Ion chromatography \\
Chloride & Silver nitrate titration (APHA 1992) & Ion chromatography \\
\hline
\end{tabular}

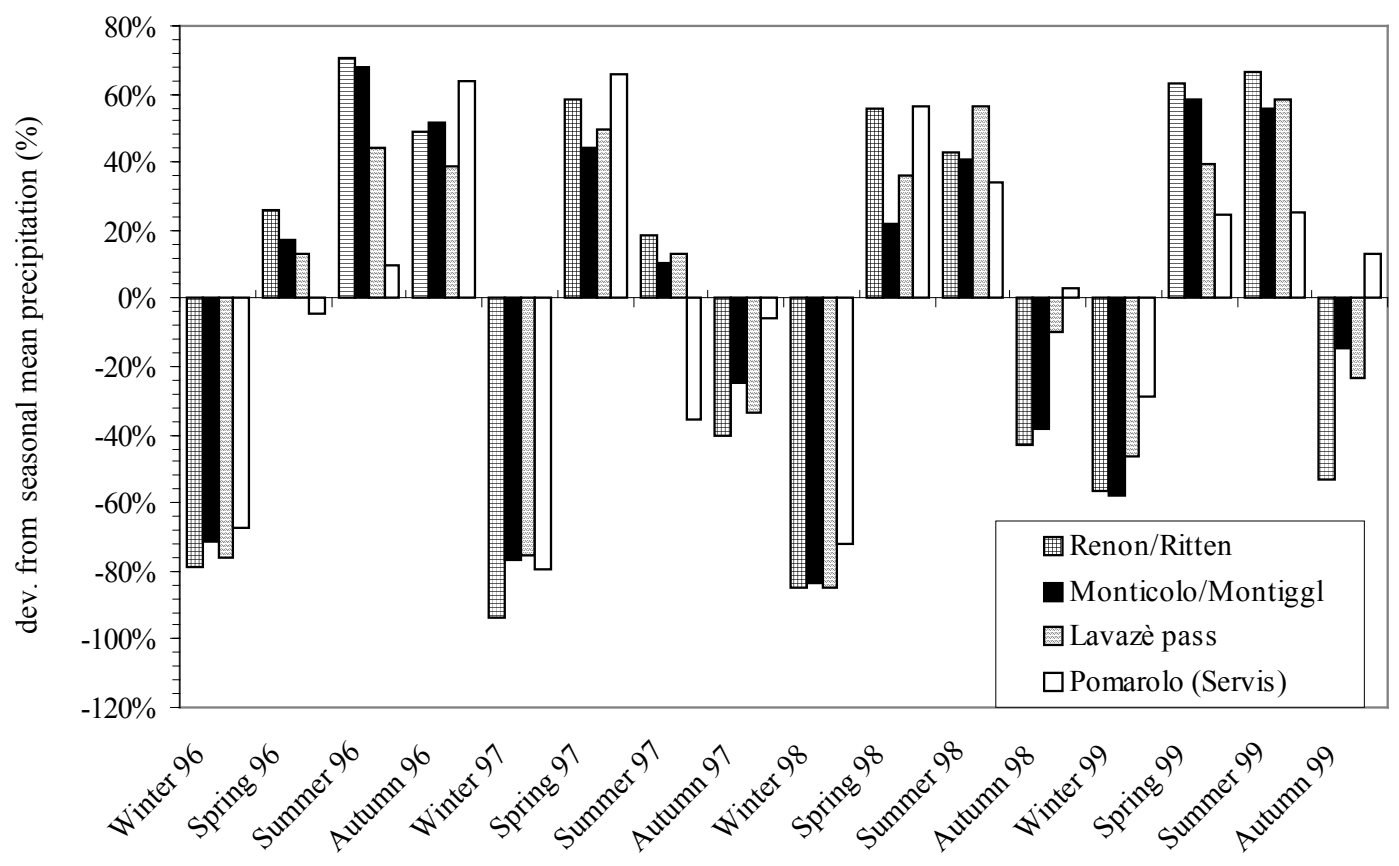

Fig. 2. Percentage of deviation from seasonal mean precipitation.

Bavarian plateau) of the Alps; and secondly the orography and the altitude of the land (Fliri 1975). The whole of the region lies in the southern Alpine watershed, and is subject to two different types of rainfall:

a) prealpine, characterised by maximum precipitation in the spring or autumn;

b) continental-alpine, characterised by maximum precipitation in the summer.

Precipitation in winter is typically low, and is mostly snow. At the sites of Lavazè Pass and Renon/Ritten the precipitation falls as snow for half the year, approximately from October to April. To stress the rainfall regime, the monthly amounts of precipitation were summarised for each season and the average seasonal precipitation calculated, highlighting the interannual trend at the four sites (Fig. 2). The seasonal distribution of the precipitation, even though for a restricted period, confirms the suggestions of Fliri, since the south-eastern site of Pomarolo is distinguished from the others in that it has a slightly different rainfall regime (Tab. 3). There is a recent trend towards a common decrease in yearly and also daily amounts of precipitation; the Hydrological Report (Prov. Aut. di Bolzano 1990) recorded an average reduction of roughly $4 \%$ in the period 1961-70 compared with previous periods. Further reductions of $3 \%$ and $5 \%$ were also recorded in the next decades (1971-80, 1981-90). The trend has been confirmed in the last few years; a similar situation is also found in the southern part of the region (Gandolfo \& Sulli 1993). During the period 1996-99 the annual quantity of precipitation at Pomarolo was $1078 \mathrm{~mm} \mathrm{y}^{-1}$, at Lavazè Pass $990 \mathrm{~mm} \mathrm{y}^{-1}$ (values partially interpolated with nearby pluviometers), at Monticolo/Montiggl $824 \mathrm{~mm} \mathrm{y}^{-1}$ and at Renon/Ritten $973 \mathrm{~mm} \mathrm{y}^{-1}$. There is quite a high coincidence of precipitation events among the four sites. In 1999 there were 13 weeks without precipitation and 39 weeks with rainfall; in $80 \%$ of the weeks the same me- 
Tab. 3. Average percentages of seasonal precipitation (from meteorological data: 1996-99).

\begin{tabular}{lccccc}
\hline Site & Winter & Spring & Summer & Autumn & Year (mm) \\
\hline Lavazè Pass & $7 \%$ & $34 \%$ & $36 \%$ & $23 \%$ & 990 \\
Pomarolo & $9 \%$ & $34 \%$ & $27 \%$ & $30 \%$ & 1078 \\
Monticolo/Montiggl & $7 \%$ & $34 \%$ & $36 \%$ & $23 \%$ & 824 \\
Renon/Ritten & $5 \%$ & $38 \%$ & $37 \%$ & $20 \%$ & 973 \\
\hline
\end{tabular}

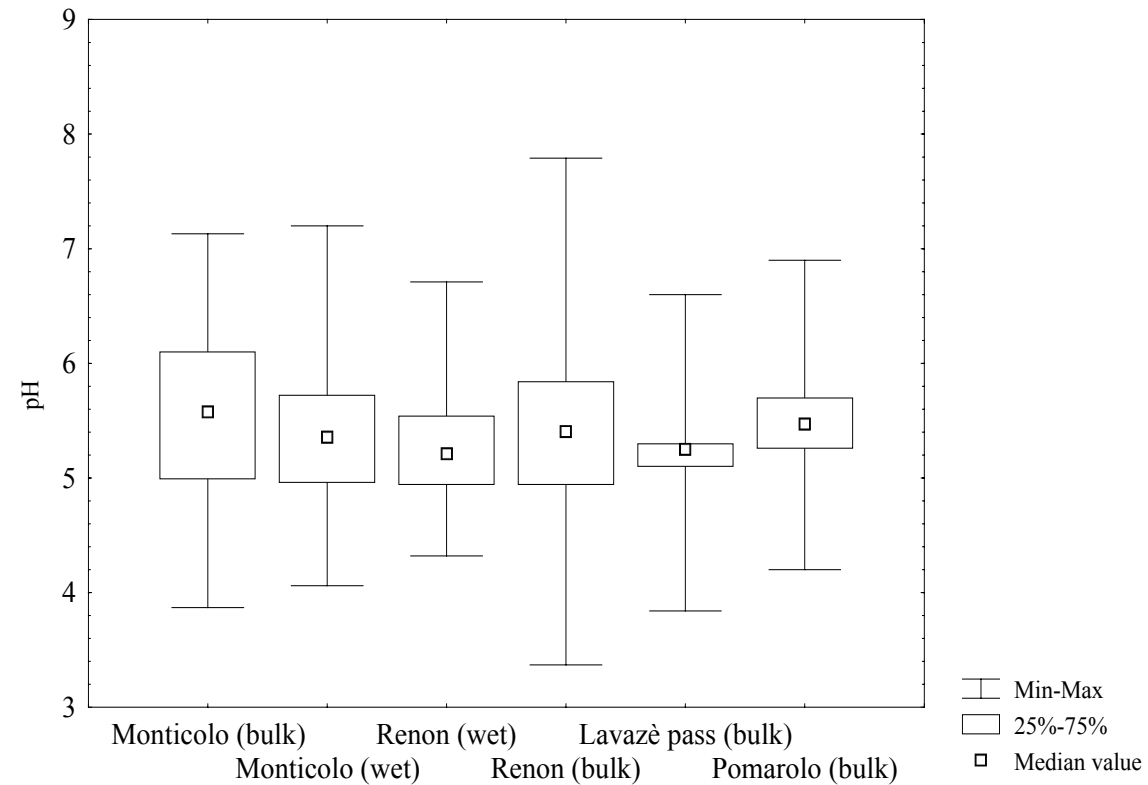

Fig. 3. Statistical values of $\mathrm{pH}$ measured at the four monitoring sites (1996-1999).

teorological conditions prevailed at all four monitoring sites, in $15 \%$ there was rainfall at three sites, and only in the remaining $5 \%$ were precipitation events recorded in only two out of four sites. This situation is highly significant as regards the phenomenology of the deposition.

\subsection{Acidity of precipitation}

In the period 1996-99 the acidity of the precipitation was measured on about 500 bulk samples and 300 wet samples as a whole. The pH values (Fig. 3) show no great differences, either as regards the four sites or the different systems of collection; somewhat lower values were registered for the wet-only samples. Of the all values recorded, only four $(<1 \%)$ had $\mathrm{pH}<4$ and nine $(\sim 1 \%) \mathrm{pH}>7$; the wet values recorded were more acid than the bulk values, due to the samples being protected from fine atmospheric dust. The same effect, because of the higher quantity of fine dust present at lower altitude in the valleys, determined less acidity in the bulk samples collected at Pomarolo (56\% of values with $\mathrm{pH}$ $<5.6)$ and Monticolo/Montiggl (48\% of values with $\mathrm{pH}$ $<5.6)$ than at the sites of Renon/Ritten $(62 \%$ of values with $\mathrm{pH}<5.6)$ and Lavazè Pass $(63 \%$ of values with $\mathrm{pH}$ $<5.6)$. The median values were in the following order:
Lavazè Pass bulk $(\mathrm{pH}=5.1)$, Renon/Ritten wet $(\mathrm{pH}=$ 5.2), Monticolo/Montiggl wet $(\mathrm{pH}=5.3)$, Renon/Ritten bulk $(\mathrm{pH}=5.4)$, Pomarolo bulk $(\mathrm{pH}=5.5)$, Monticolo/Montiggl bulk ( $\mathrm{pH}=5.7)$.

The "throughfall" precipitation shows slightly lower acidity than that in the open field because of the buffering ions released from the foliar surface. The stemflow water collected at the site of Renon/Ritten was slightly more acid compared with the free acidity measured on open field samples; this is due to the characteristics of the bark of the conifers.

The ionic composition of the rainfall in the period 1996-99, analysed in the two above-mentioned laboratories (see Tab. 2), has been statistically elaborated and is presented graphically (Fig. 4). Only the sites of Monticolo/Montiggl and Renon/Ritten are supplied with wetonly sample collectors; figure $4 \mathrm{a}$ shows that the concentrations of most ions are similar, although the site of Monticolo/Montiggl has a slightly higher ionic content. Ion concentrations are greatest at Pomarolo, followed by Monticolo/Montiggl, probably due to their closeness to the Po Plain and to the main urban areas of the region. The conductivity values show that the samples collected at Renon/Ritten and Lavazè Pass have a lower solute content than the samples collected at the other two sites, confirming the results for the main ions. 


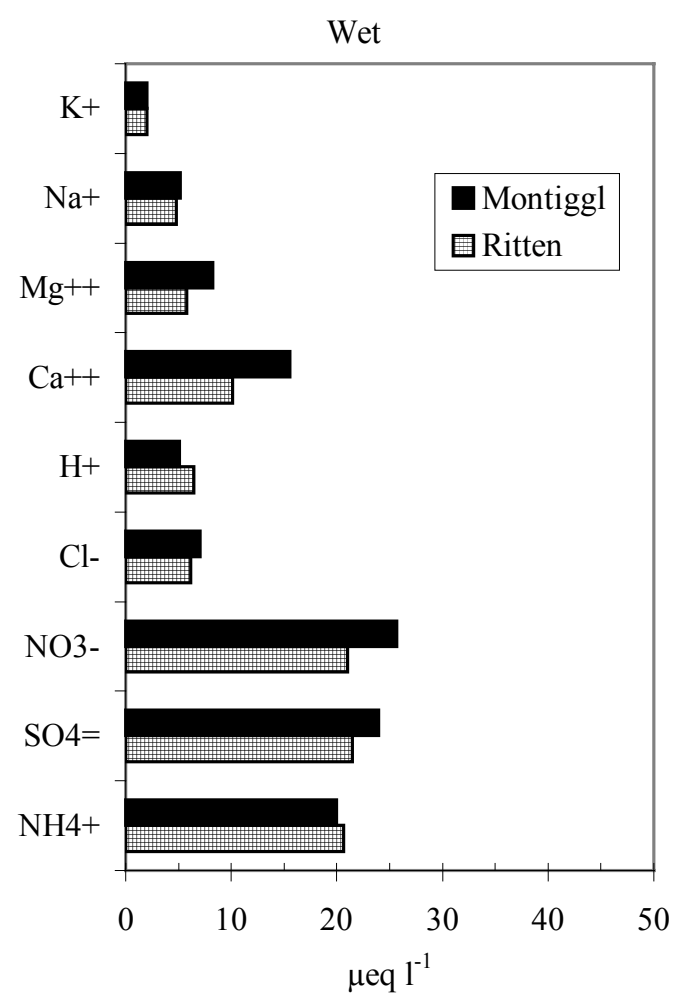

Throughfall

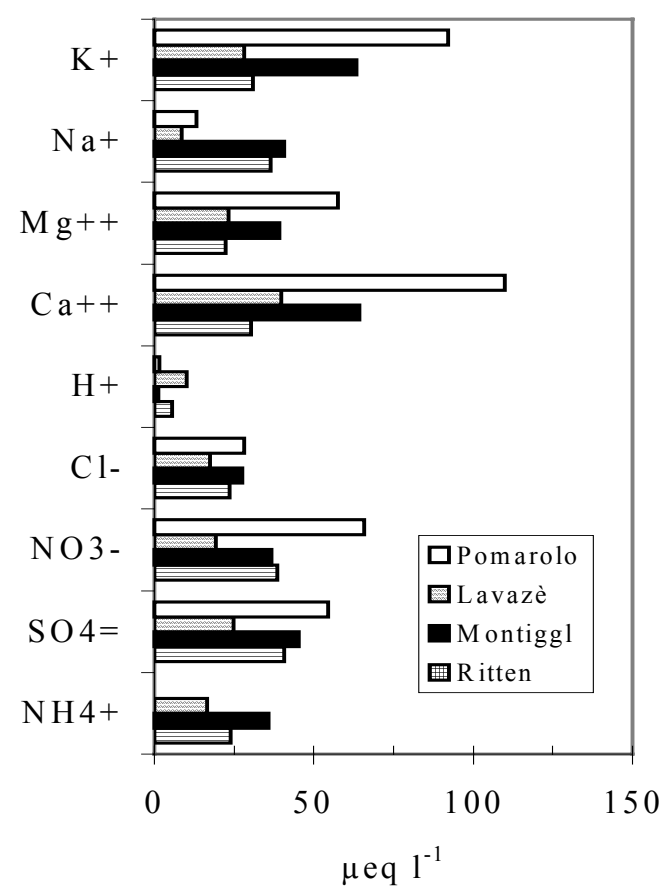

Bulk

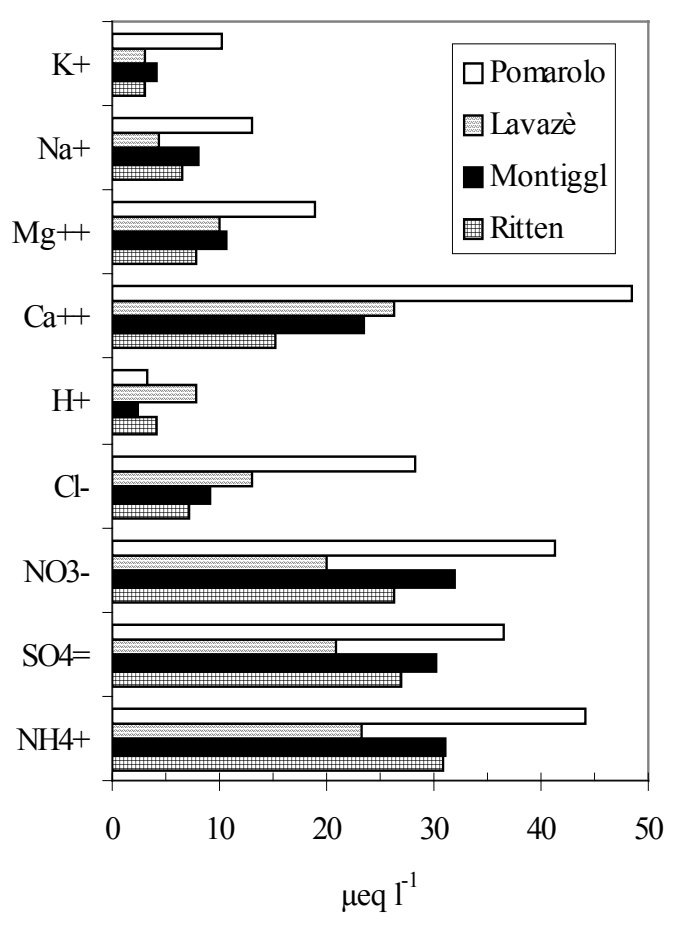

Stemflow

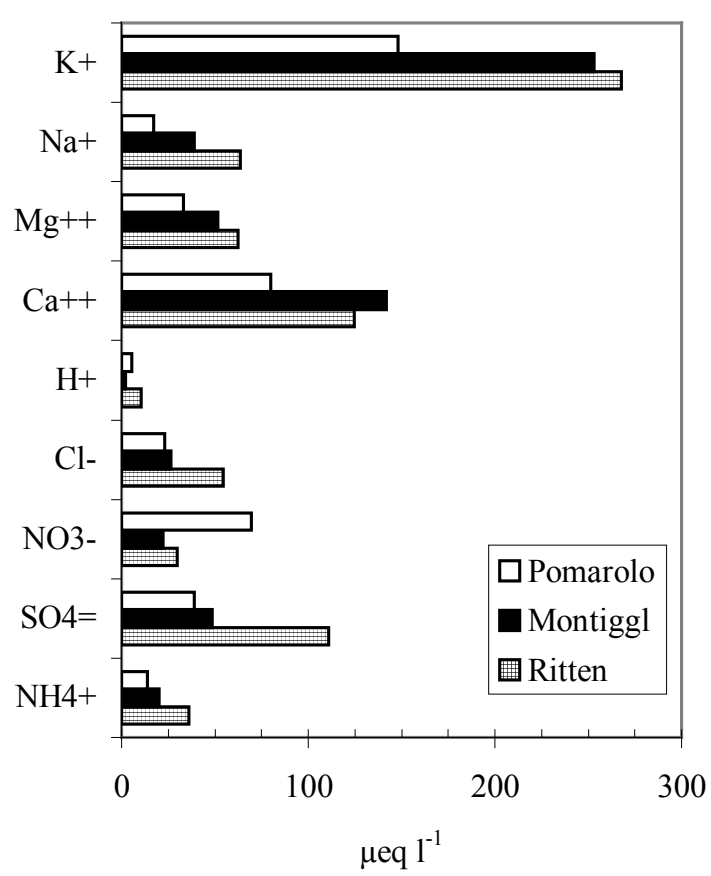

Fig. 4. Median values of weekly concentrations for the period 1996-99. 
Tab. 4. Annual average depositions $\left(\mathrm{kg} \mathrm{ha}^{-1} \mathrm{y}^{-1}\right)$.

\begin{tabular}{|c|c|c|c|c|c|c|}
\hline & $\mathrm{S}-\mathrm{SO}_{4}{ }^{=}$ & $\mathrm{N}-\mathrm{NO}_{3}^{-}$ & $\mathrm{N}-\mathrm{NH}_{4}^{+}$ & $\mathrm{K}^{+}$ & $\mathrm{Ca}^{++}$ & $\mathrm{Mg}^{++}$ \\
\hline \multicolumn{7}{|c|}{ Renon/Ritten (1994-99) } \\
\hline bulk & 3.89 & 3.65 & 4.37 & 2.20 & 3.02 & 0.79 \\
\hline wet & 3.53 & 2.95 & 3.48 & 0.80 & 2.28 & 0.60 \\
\hline throughfall & 5.61 & 3.46 & 2.43 & 18.86 & 7.71 & 2.84 \\
\hline stemflow & 0.005 & 0.003 & 0.003 & 0.029 & 0.007 & 0.002 \\
\hline \multicolumn{7}{|c|}{ Monticolo/Montiggl (1994-99) } \\
\hline bulk & 3.59 & 3.30 & 3.35 & 1.62 & 3.61 & 0.82 \\
\hline wet & 3.33 & 2.88 & 2.71 & 1.09 & 2.95 & 0.66 \\
\hline throughfall & 4.46 & 3.14 & 3.64 & 21.67 & 7.27 & 2.91 \\
\hline stemflow & 0.030 & 0.010 & 0.010 & 0.251 & 0.074 & 0.018 \\
\hline \multicolumn{7}{|c|}{ Passo Lavazè (1998-99) } \\
\hline bulk & 3.67 & 3.08 & 3.63 & 1.32 & 5.77 & 1.33 \\
\hline throughfall & 3.39 & 2.31 & 1.97 & 9.42 & 6.85 & 2.43 \\
\hline \multicolumn{7}{|c|}{ Pomarolo (1999) } \\
\hline bulk & 6.03 & 5.99 & 6.38 & 4.13 & 10.01 & 2.37 \\
\hline throughfall & 7.40 & 7.78 & - & 30.45 & 18.61 & 5.92 \\
\hline
\end{tabular}

The differences in the ionic concentrations are explained by the geopedological characteristics of a site (calcium, magnesium, potassium) and its vegetative cover (ammonium), or by its distance from the sea (chlorine, sodium), or by its closeness to urban and industrial areas (sulphur, nitrogen ...); these factors have a major role in establishing the ionic composition of the precipitation, along with the meteorological factors that caused the event. The "throughfall" precipitation shows the same order of concentration of ions among the four monitoring sites, and this could confirm that dry and wet deposition are, in the long term, influenced by the same factors. The concentrations measured in the stemflow samples mainly reveal the difference between the coniferous stands of Renon/Ritten, and the broadleaf stands of Monticolo/Montiggl and Pomarolo. The data of Lavazè are omitted because of the low number of total samples and the great variability of the values. Stemflow depositions are influenced primarily by the size, age and shape of the trees, and the data consequently vary widely. The stemflow amounts of water sampled were low for all four stations, so that the calculated deposition, despite the high concentrations, was so low that its contribution to the total forest deposition is practically insignificant.

At the sites of Monticolo/Montiggl and Renon/Ritten in the period 1996-1999 the average net acidity of wet samples was $-2 \pm 4 \mathrm{mmol} \mathrm{m} \mathrm{m}^{-2}$ and -0.5 $\pm 5 \mathrm{mmol} \mathrm{m}^{-2} \mathrm{y}^{-1}$ respectively, i.e. slightly basic. The potential acidity at Renon/Ritten $\left(50 \pm 5 \mathrm{mmol} \mathrm{m}^{-2} \mathrm{y}^{-1}\right)$ was higher than at Monticolo/Montiggl $(36 \pm 5 \mathrm{mmol}$ $\mathrm{m}^{-2} \mathrm{y}^{-1}$ ) because of the higher input of ammonium. In the precipitation under the canopy the order was inverted: Monticolo/Montiggl showed higher values than Renon/Ritten, both for net and potential acidity, probably because of the greater presence of dust in the low strata of the atmosphere and the higher ion release from broadleaf than from conifer crowns.

Because of some interruptions in the continuity of sampling and analysis, it is not possible to make a similar evaluation of acidity for the sites of Lavazè and Pomarolo; nevertheless, given their geographical proximity and their similar pluviometric regime, the Renon/Ritten results can be reasonably extended to the Lavazè area at least.

\subsection{Deposition}

The amounts of "open field" precipitation sampled were between $25 \%$ to $35 \%$ higher than the "throughfall" precipitation amounts, with small differences between coniferous and broadleaf stands. The precipitation at Lavazè and Renon/Ritten falls as snow for much of the year (from October to April), and this influences both the quantity and the quality of the precipitation intercepted under the crown. Another factor that influences the deposition under the crown is the inner variability of the "throughfall" precipitation caused by differences in the structure of forest stands and the different sizes of the trees: the amount of annual precipitation collected in the 16 samplers varies by approximately $37 \%$ on average at Lavazè Pass and by $21 \%$ at Pomarolo. The deposition values were calculated from weekly samples for Monticolo/Montiggl and Renon/Ritten, whereas for Lavazè and Pomarolo they are estimated from the median values reached in the period. The average annual deposition of the main components (Tab. 4) shows that bulk deposition is higher than wet deposition, as a consequence of the fact that samples can be exposed to atmospheric dry contamination between the single precipitation events.

As is known, "throughfall" deposition is higher than open field deposition in spite of the lower quantity of precipitation; only ammonium deposition does not follow this general rule, since the foliar organs can adsorb it from the air and utilise it for nutrition. The "throughfall" deposition depends both on dry deposition on the crown and leaching from the foliar tissues; seasonal variations due to the climatic regime play an important role, but are partly levelled out by synthesizing the data through the pluriannual median, as has been done in this 

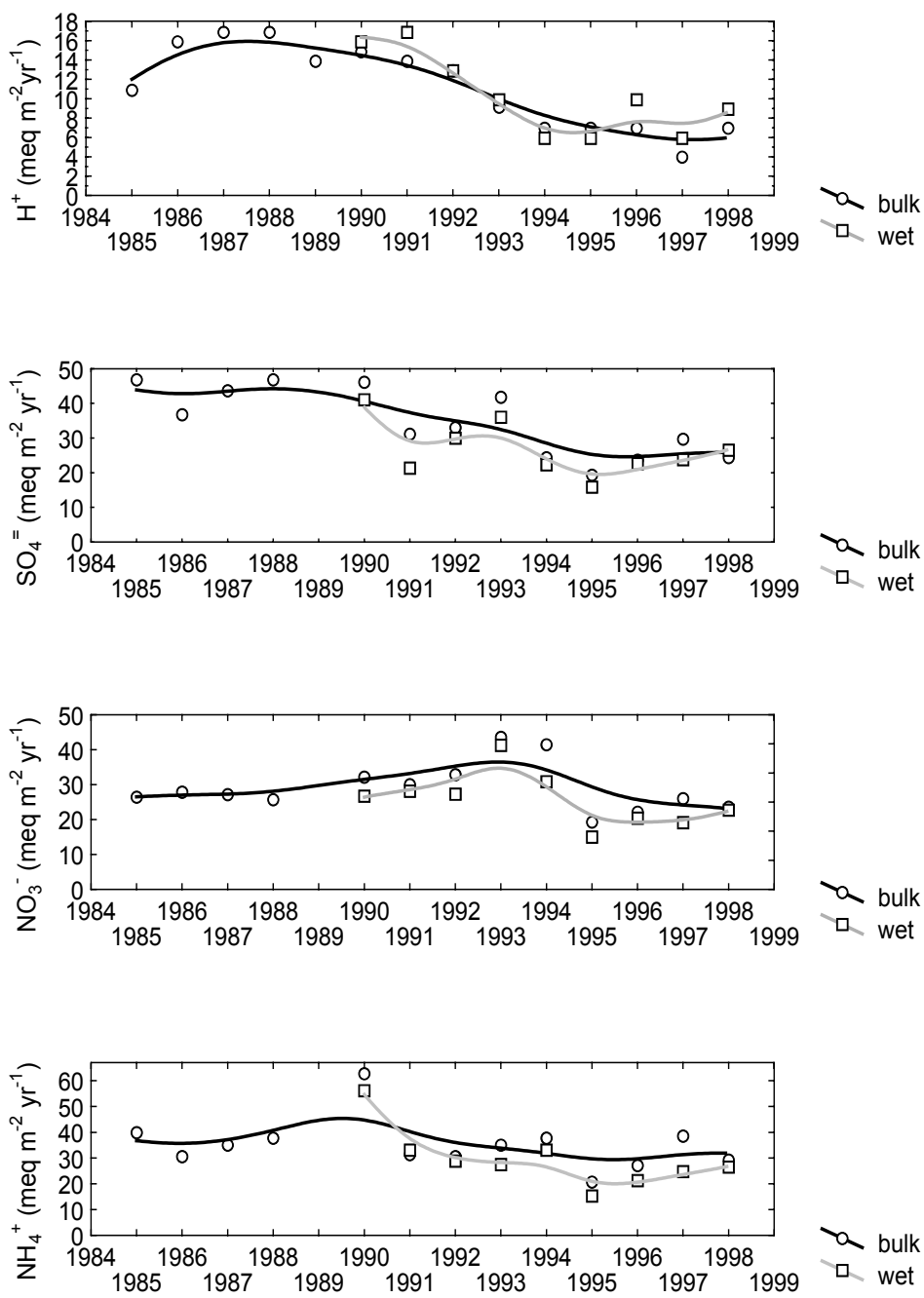

Fig. 5. Annual average depositions in weekly samples at Renon/Ritten, with least squares fitting.

study. The sulphate throughfall deposition is considerably higher than open field deposition, due to the influence of dry deposition. Throughfall nitrate deposition is similar to that of the open field; the site of Pomarolo shows the highest nitrate concentrations and deposition values, and this could be related to the proximity of the Brenner motorway; nitrogen components of anthropogenic origin are to a great extent generated by vehicular emissions. All sites show a considerable increment in the deposition of some cations $(\mathrm{K}, \mathrm{Ca}, \mathrm{Mg})$ whose contribution is mainly due to the release from foliar organs during the vegetational season. The observations carried out in the framework of the permanent European monitoring plots do not however reveal damage to leaves severe enough to account for this source of mineral enrichment to any significant extent.

\subsection{Long term trends}

The reduction in sulphur emissions in Europe in the wake of emission control measures is leading to de- creased levels of sulphur in atmospheric concentration and deposition. Although there was a substantial reduction in sulphur emissions, the output of $\mathrm{NO}_{\mathrm{x}}$ changed very little during the same period (Mylona 1996). These changes can be clearly seen in the sites of the South Tyrol. Atmospheric sulphate levels have declined greatly during the last six years, while nitrogen deposition initially showed a tendency to increase up to 1994 , declining after this date but with a subsequent tendency towards a slight increase (Fig. 5). The ratio between sulphate and nitrate depositions has changed from $2: 1$ in 1984 to $1: 1$ in recent years. Trend and slope evaluation were analysed using linear regression on deseasonalized monthly data and using the seasonal Kendall test (Tait $\&$ Thaler 2000). The decrease in sulphate concentrations is highly significant $(\mathrm{p}<1 \%)$, while the change in nitrate concentrations is documented only for the wet samples, where it shows a decrease over the last eight years. Ammonium deposition also showed a declining trend, which however is highly significant only for the wet 
Tab. 5. Median values of weighted monthly concentrations in the soil water at four monitoring sites. *, concentration not assessed; unit: $\mu$ eq $1^{-1}$.

\begin{tabular}{lcccc}
\hline & $\begin{array}{c}\text { Renon/Ritten } \\
1994-99\end{array}$ & $\begin{array}{c}\text { Monticolo/Montiggl } \\
1994-99\end{array}$ & $\begin{array}{c}\text { Lavazè } \\
1997-99\end{array}$ & $\begin{array}{c}\text { Pomarolo } \\
1997-98\end{array}$ \\
\hline $\mathrm{pH}$ & 5.6 & 5.4 & 4.4 & 6.9 \\
$\mathrm{SO}_{4}{ }^{-}$ & 56.1 & 58.6 & 28.5 & 79.7 \\
$\mathrm{NO}_{3}$ & 9.7 & 10.7 & 16.4 & 33.2 \\
$\mathrm{NH}_{4}{ }^{+}$ & 1.4 & 1.6 & $*$ & $*$ \\
$\mathrm{TIN}^{-}$ & 12.4 & 17.1 & $*$ & $*$ \\
$\mathrm{Cl}^{-}$ & 17.4 & 20.2 & 16.9 & 29.2 \\
$\mathrm{Ca}^{++}$ & 43.9 & 95.7 & 15.0 & 426.6 \\
$\mathrm{~K}^{+}$ & 23.2 & 28.0 & 12.8 & 35.8 \\
$\mathrm{Na}^{+}$ & 35.8 & 25.3 & 17.4 & 28.3 \\
$\mathrm{Mg}^{++}$ & 30.1 & 28.0 & 30.4 & 130.3 \\
\hline
\end{tabular}

deposition records and for the non-parametric test. A decreasing tendency in the calcium deposition values for South Tyrol was also observed, again highly significant only for the wet samples and for the non-parametric test. The recorded decrease in alkaline dust might have partly counteracted the decline in acidic emissions, but on the whole, the long-term modifications in atmospheric precipitation chemistry recorded show a net decrease in the total acidifying level.

\subsection{Soil water}

The variability in chemical concentrations observed between the experimental sites probably depends on the differences in sampling depths and in vegetational cover, hydrology and lithology. The soil water was found to be most acidic at Lavazé, probably because of the greater sampling depth and/or the sylvicultural treatments and litterfall accumulation characteristic of the site, while it is well buffered at Pomarolo. The sites of Monticolo/Montiggl and Renon/Ritten show very similar concentrations of the dissolved ions (except for calcium), while the limestone zone of Pomarolo displays the highest concentrations (Tab. 5). The low nitrate content of the soil water and the virtual absence of ammonium indicate that there is no nitrogen saturation of the soil.

An evaluation of these data is difficult also because of the relative scarcity of published data on the chemical analysis of soil water in forested areas, where pedologic, climatic and sylvicultural characteristics play a fundamental role in the wide variability of ionic concentrations.

The differences among the four sites could be explained both in terms of the different sampling methods used (see the chapter on methodology) and with regard to the lithologic substratum and past land use. The Lavazè area is in fact the only one that has always been forested, whereas Renon/Ritten was pasture land up to the 50s and the other two sites were coppice woods. Coniferous stands produce very acidic litter, which can explain the lower values of $\mathrm{pH}$ at Lavazè. A chemical analysis of the soils, carried out simultaneously for the four sites in 1993, showed that the mean $\mathrm{pH}$ was 2.9 for Lavazè and 3.3 at Renon/Ritten, while the other sites showed $\mathrm{pH}$ of $>4$ (Monticolo/Montiggl) and $>5$ (Pomarolo).

\section{DISCUSSION}

The level of contamination resulting from the deposition values registered both in the open field and for throughfall and stemflow precipitation is lower than in the neighbouring areas (Mosello \& Marchetto 1996), on the one hand because of the lower amount of precipitation falling in the four regional monitoring sites, and on the other hand because of the scarce local emissions.

This suggestion is confirmed by comparing the precipitation amounts recorded at the two sites of Lavazè and Renon/Ritten with those recorded at similar sites, also located in typical Alpine forest, in the neighbouring regions. Amounts of precipitation in 1998 and 1999 were between $35 \%$ and $90 \%$ lower than in the monitoring sites of Lombardy, Veneto and Friuli Venezia Giulia (Mosello et al. 1999b, 2000). The concentrations of the main acidifying components recorded in Trentino-South Tyrol were also lower: in open field samples, sulphate was $40 \%$ and nitrate $17 \%$ lower than in the other regions. Throughfall precipitation showed similar ratios. Concentrations and, even more, deposition values of acidifying components are therefore lower in TrentinoSouth Tyrol than in the neighbouring regions. A comparison with the regions north of the Alps would lead to similar results (Meesenburg \& Meiwes 1999). The reduction in acidic atmospheric input observed during the last few years both on the national monitoring network (Novo \& Belgiovine 1996) and, generally, on the European ICP-IM network (Vuorenmaa 1997), due essentially to the use of fuels with lower sulphur contents, has produced a further reduction of the already moderate pollutant effect on ecosystems and a decreasing acidity of the atmospheric precipitation (Tait \& Thaler 2000). A large proportion of the pollutants transported from northern and eastern Europe is probably stopped both by Alpine watersheds, characterised by mountain groups with altitudes up to over $3000 \mathrm{~m}$ a.s.l., and by the gen- 
eral model of atmospheric circulation predominating in this geographical context, as pointed out by Fliri (1975). On the other hand, the region is exposed to contaminants coming from urban areas of northern Italy, so that a decreasing gradient of ionic concentrations in the precipitation from the southern to the northern sites is noticeable. A study carried out to evaluate the diffusion of the ozone precursors $\left(\mathrm{NO}_{\mathrm{x}}, \mathrm{VOC}\right)$, according to the simulation of a meteorological mesoscale model (REWIH3D), showed that the mechanism of transboundary mass transport involves the central axis of the Alps (Adige valley), with the south and south-western components prevailing (Schlager \& Graf 1993). This main direction corresponds to the transport of pollutants from the Po Plain.

The available data show that, on an annual average, no acidic deposition has been recorded in the last few years, although this does not exclude single acidic events. Differences in pedologic substratum can nevertheless produce various consequences in the different monitoring sites. The most sensitive site in this respect seems to be Lavazè.

\section{CONCLUSIONS}

The role played by local sources of emission, particularly the towns of Bolzano/Bozen and Trento, should not be underestimated either; their impact means that the sites located in the Adige Valley (Monticolo/Montiggl and Pomarolo) show a higher level of acidifying substances. The Brenner motorway, the main communication lane between northern Europe and Italy, also constitutes an appreciable source of inorganic nitrogen, adding to the acidic input. This will be a major factor in the development of future investigations, because the eutrophication of soils due to nitrogen enrichment is thought to be one of the main causes of forest decline (Sanasilva 1989). The current level of deposition seems to be more or less balanced with the flux of inorganic substances in the forest ecosystems. Furthermore, the water leaching through the soil does not carry concentrations of inorganic ions sufficient to cause changes in the properties of the soil. Forest damage in Trentino-South Tyrol, although not severe, seems therefore to be mainly caused by specific local climatic conditions which foster the incidence of various diseases (fungi, insects). "Frost drought" damage or winter desiccation can be the breaking out cause of physiological change, for instance, either in single trees or in coniferous stands at high altitudes near the timberline. The resistance of trees to drought, particularly in Picea abies and Larix decidua, is correlated with the appropriate development of needles and shoots, and varies either with the climatic conditions of the previous summer and during the winter, or with altitude (Tranquillini 1979); in addition, a recent investigation (Ambrosi \& Minerbi 2001) concluded that photosynthetic activity can also sometimes occur during the "vegetation repose period", if there is a rise in atmospheric temperature. These situations also result in reduced physiological functionality of the crown. The data collected up to now suggest therefore that "atmospheric deposition" is not the sole agent responsible for the alteration of forestry ecosystems. A multifactorial approach to the problem might help to clarify the relative importance of each of the causes affecting the evolution of forestry stands in Alpine regions.

\section{ACKNOWLEDGMENTS}

This paper was prepared within the contract between the Ministry for Agriculture and Forestry Policy - National Forest Service, Italy. The Authors are grateful to the Forest Administration staff of the Autonomous Province of Bolzano/Bozen and Trento.

\section{REFERENCES}

APHA, AWWA, WEF. 1992. Standard methods for the examination of water and wastewater. Am. Publ. Health Ass., $18^{\text {th }}$ ed.

Ambrosi, P., F. Bertolini, E. George, S. Minerbi \& C. Salvadori. 1998. Integrated monitoring in Alpine forest ecosystems in Trentino and south Tyrol, Italy. Chemosphere, 36, Nos 4/5: 1043-1058.

Ambrosi, P. \& S. Minerbi 2001. Nuovi approcci nella gestione delle problematiche sanitarie dei boschi alpini. Annali dell'Accademia Italiana di Scienze Forestali, XLIX-L: 1522.

Ballarin Denti, A., S. Mariano Cocucci \& F. Sartori. 1998. Monitoraggio delle foreste sotto stress ambientale. Fondazione Lombardia per l'Ambiente. Milano.

EMEP Co-operative programme for Monitoring and Evaluation of the Long-range Trasmission of Air pollutants in Europe. 1996. EMEP Manual for sampling and chemical analysis. Norwegian Institute for Air Research.

Fliri, F. 1975. Das Klima der Alpen im Raume von Tirol. Universitätverlag Wagner, Innsbruck-München: 454 pp.

Gandolfo, C. \& M. Sulli 1993. Studi sul clima del Trentino per ricerche dendrocronologiche e di ecologia forestale. Ed. Prov. Aut. di Trento: 83 pp.

Gran, G. 1952. Determination of the equivalence point in potentiometric titration II. Analyst, 77: 661-671.

Meesenburg, H. \& K. J. Meiwes. 1999. Bedeutung des langzeitmonitorings am Beispiel des Solling-Projektes. Forstwirtschaften in NiederSachsen. Niedersächsische Forstliche Versuchsanstalt, Göttingen.

Mylona, S. 1996. Sulphur dioxide emissions in Europe 18801991 and their effect on sulphur concentrations and depositions. Tellus, Series B Chemical and Physical Meteorology, 48(5): 662-689.

Mosello, R. \& A. Marchetto. 1996. Chemistry of atmospheric wet deposition in Italy: results of five year study. Ambio, 25(1), Feb 1996.

Mosello, R., M. Bianchi, M.C. Brizzio, H. Geiss, W. Leyendecker, A. Marchetto, D. Rembges, G.A. Tartari \& H. Muntau. 1999a. Results from the laboratories participating in the ICP Forests. AQUACON MedBas Project Subproject No. 6, Acid rain analysis, Intercomparison 1/98. Joint Research Centre. EUR 18135 EN: 64 pp.

Mosello, R., A. Marchetto, M.C. Brizzio, W. Leyendecker, D. Rembges, D. Abruzzese, G.A: Tartari \& S. Piazza 1999b. La chimica delle deposizioni atmosferiche nelle aree del programma CONECOFOR nell'anno 1998. C.N.R. Ist. Ital. Idrobiol. Verbania-Pallanza: 22 pp. 
Mosello, R., A. Marchetto, M.C. Brizzio \& D. Rembges. 2000. La chimica delle deposizioni atmosferiche nelle aree del programma Con.Eco.For nell'anno 1999. C.N.R. Ist. Ital. Idrobiol. Verbania-Pallanza: $32 \mathrm{pp}$.

Novo, A. \& N. Belgiovine. 1996. Analisi del trend nei campioni di deposizione umida della rete ENEL. ENEL/CRAM1996005, Dir. Studi e Ricerche, Milano.

Provincia Autonoma di Bolzano. 1994. Precipitazioni: 70 anni di osservazioni in Alto Adige. Ed. Alto Adige: $185 \mathrm{pp}$.

Sanasilva. 1989. Danni boschivi di nuovo tipo ed inquinamento atmosferico. CH-Bellinzona/TI: $61 \mathrm{pp}$.

Schlager, H. \& J. Graf. 1993. Projekt MEMOSA. Messungen und Modellierung des Scahdstoffverhaltens in Alpenbereich. DLR Wessling, (D): $10 \mathrm{pp}$.
Tait, D. \& B. Thaler. 2000. Atmospheric deposition and lake chemistry trends at a high mountain site in the eastern Alps. J. Limnol., 59(1): 61-71.

Tranquillini, W. 1979. Physiological Ecology of the Alpine Timberline. Ecological Studies 31. Springer Verlag, Berlin-Heidelberg: XI + $131 \mathrm{pp}$.

Verdow, H., C. van Echteld \& E. Dekkers. 1978. Ammonia determination based on indophenol formation with sodium salycilate. Wat. Res., 12: 399-402.

Vuorenmaa, J. 1997. Trend assesment of bulk and throughfall deposition and runoff water chemistry at IM sites. In: Kleemola S., Forsius M. (Eds), 6th Annual Report 1997. UN-ECE ICP Integrated Monitoring. Finnish Environment Institute, Helsinki FI. 116: 24-36.

Wagner, R. 1969. Neue Aspekte zur Stickstoffanalytik in der Wasserchemie. Vom Wasser, 36: 263-318. 